\title{
What does phenotype have to do with it?
}

\section{OPEN}

Stefan M. Pulst, MD, Dr med

Correspondence to Dr. Pulst: stefan.pulst@hsc.utah.edu

Neurol Genet

2017;3:e175; doi: 10.1212/ NXG.0000000000000175
A recurring theme in this column and in articles published in Neurology ${ }^{\circledR}$ Genetics is the problem of interpreting DNA variants, ever more present as nextgeneration sequencing invariably leads to the identification of multiple rare variants in a given individual. This is discussed in this issue in 2 articles and an accompanying editorial. ${ }^{1-3}$

The Berkovic group critically examines reported variants in autosomal dominant epilepsies. ${ }^{1}$ They make use of the ExAC database and in a 2nd analysis of the expanded ExAC V2 plus gnomAD databases with whole-exome and whole-genome sequencing data on 123,136 individuals and 15,496 individuals, respectively. They find that occurrence of a variant more than once in this database greatly reduces the probability that the respective variant is disease causing with high penetrance. Their analysis also reflects on the potentially erroneous assignments of DNA variants in EFHC1 and SRPX2 as disease causing in familial epilepsy syndromes.

The report by McNeil and colleagues ${ }^{2}$ describes a molecular genetic case study of a patient presenting with an unusual leukodystrophy. The authors initially identify compound heterozygous mutations in the EARS2 gene that led to reduction in protein levels by $70 \%$. But as Massimo Pandolfo points out in the accompanying editorial, ${ }^{3}$ the typical clinical and imaging phenotypes associated with mutations in EARS2 did not fit the phenotype of the patient. McNeill et al. were aided by a prior study of this patient that had also shown compound heterozygous mutations in SNORD118, encoding a small nucleolar RNA involved in ribosome biogenesis. In addition, the phenotype associated with SNORD118 mutations actually fit the patient much better! We need to realize that the clinical or imaging subtleties of leukoencephalopathy, brain calcifications, and cysts vs leukoencephalopathy with thalamus and brainstem involvement and high lactate may escape the non-subspecialist.

Several years ago, we came across a similar scenario. ${ }^{4}$ By screening patients with autosomal dominant ataxias for mutations in $K C N C 3$, the gene encoding the $\mathrm{Kv} 3.3$ potassium channel, we identified a Gly263Asp amino acid substitution. This variant occurred in an amino acid that was evolutionarily conserved, but not nearly to the same degree as amino acids changed by other verified KCNC3 mutations. Mutation prediction programs predicted this amino acid substitution to be deleterious and indeed, on introducing the variant Kv3.3 channel into frog oocytes, the biophysical characteristics were altered. What saved the day for us was the fact that the patient had a concomitant repeat expansion mutation in $C A C N A 1 A$, and the $K C N C 3$ variant did not segregate with other affected family members. In retrospect, a tip-off might have been that the biophysical changes in channel function, although significant, were relatively mild compared with the gain-of-function Phe448Leu mutation associated with early onset ataxia. $^{5}$ Thus, significant may not always equal relevant.

As Pandolfo points out, it is important to examine the phenotype in its relationship to the gene variant and established phenotypes. Our colleagues in neuroradiology know this well and frequently add to their reports "clinical correlation is needed." The same applies to the interpretation of in vitro assays. The compound heterozygous variants in EARS2 described by McNeill et al. reduced protein levels to only $30 \%$ in the patient's skin fibroblasts, probably not a sufficient reduction to be functionally important. The next challenge will be understanding the implications of changes in functional assays that may be significant in the context of in vitro studies, but may not be significant at the organismal level. Maybe biochemists and neurophysiologist need to append "clinical correlation required!"

\section{STUDY FUNDING}

No targeted funding reported.

\section{DISCLOSURE}

S.M. Pulst serves on the editorial boards of Journal of Cerebellum, NeuroMolecular Medicine, Continuum, Experimental Neurology, Neurogenetics, and Nature Clinical Practice Neurology; receives research support from NIH, Target ALS, National Ataxia Foundation, and ISIS Pharmaceuticals; has consulted for Ataxion Therapeutics and served on a speakers' bureau for Athena Diagnostics, Inc.; is a stockholder of Progenitor Life

From the Department of Neurology, University of Utah, Salt Lake City.

This is an open access article distributed under the terms of the Creative Commons Attribution-NonCommercial-NoDerivatives License 4.0 (CC BY-NC-ND), which permits downloading and sharing the work provided it is properly cited. The work cannot be changed in any way or used commercially without permission from the journal. 
Sciences; has received license fee payments from Cedars-Sinai Medical Center; holds patents for Nucleic acids encoding ataxin-2 binding proteins, Nucleic acid encoding Schwannomin-binding proteins, Transgenic mouse expressing a polynucleotide encoding a human ataxin-2 polypeptide, Methods of detecting spinocerebellar ataxia- 2 nucleic acids, Nucleic acid encoding spinocerebellar ataxia-2 to, Schwannomin-binding proteins, and Compositions and methods for spinocerebellar ataxia; and receives an honorarium from the AAN as the Editor of Neurology: Genetics. Go to Neurology.org/ng for full disclosure forms.

\section{REFERENCES}

1. Bennett CA, Petrovski S, Oliver KL, Berkovic SF. ExACtly zero or once: clinically helpful guide to assessing genetic variants in mild epilepsies. Neurol Genet 2017;3:e163. doi: 10.1212/NXG.0000000000000163.
2. McNeil N, Nasca A, Reyes A, et al. Functionally pathogenic EARS2 variants in vitro may not manifest a phenotype invivo. Neurol Genet 2017;3:e162. doi: 10.1212/NXG. 0000000000000162.

3. Pandolfo M. This variant alters protein function, but is it pathogenic? Neurol Genet 2017;3:e173. doi: 10.1212/ NXG.0000000000000173.

4. Figueroa KP, Waters MF, Garibyan V, et al. Frequency of KCNC3 DNA variants as causes of spinocerebellar ataxia 13 (SCA13). PLoS One 2011;6:e17811.

5. Waters MF, Minassian NA, Stevanin G, et al. Mutations in voltage-gated potassium channel KCNC3 cause degenerative and developmental central nervous system phenotypes. Nat Genet 2006;38:447-451. 


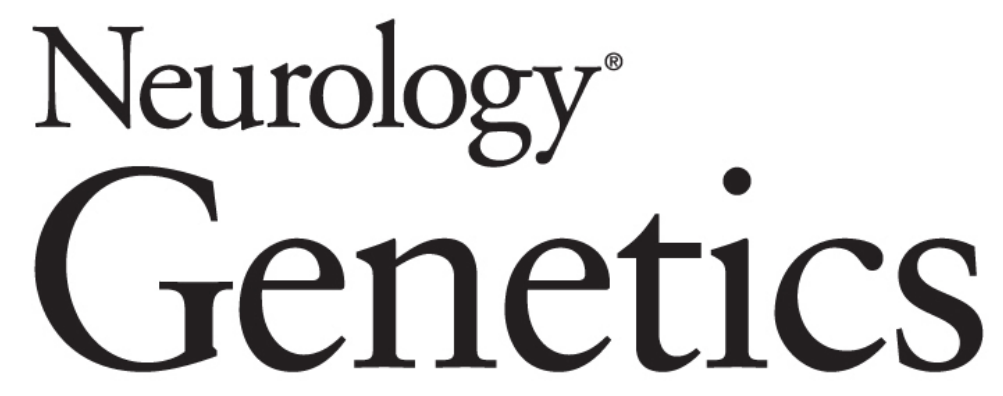

\author{
What does phenotype have to do with it? \\ Stefan M. Pulst \\ Neurol Genet 2017;3; \\ DOI 10.1212/NXG.0000000000000175
}

This information is current as of August 17, 2017

\section{Updated Information \&} Services

References

Permissions \& Licensing

Reprints including high resolution figures, can be found at: http://ng.neurology.org/content/3/4/e175.full.html

This article cites 5 articles, 3 of which you can access for free at: http://ng.neurology.org/content/3/4/e175.full.html\#\#ref-list-1

Information about reproducing this article in parts (figures,tables) or in its entirety can be found online at:

http://ng.neurology.org/misc/about.xhtml\#permissions

Information about ordering reprints can be found online: http://ng.neurology.org/misc/addir.xhtml\#reprintsus

Neurol Genet is an official journal of the American Academy of Neurology. Published since April 2015, it is an open-access, online-only, continuous publication journal. Copyright Copyright $\odot 2017$ The Author(s). Published by Wolters Kluwer Health, Inc. on behalf of the American Academy of Neurology. All rights reserved. Online ISSN: 2376-7839.

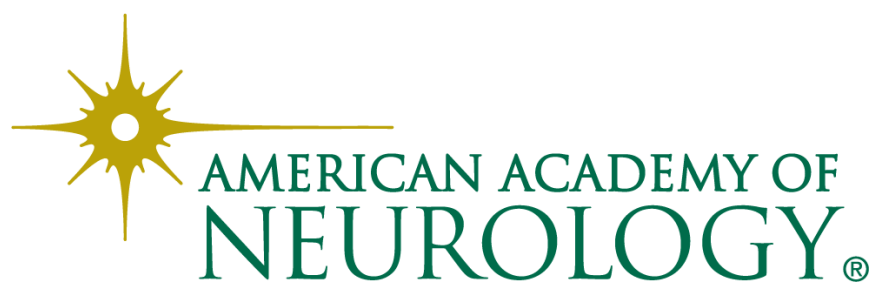

